\title{
CARBOXYPEPTIDASE Y CATALYZED PEPTIDE SYNTHESIS USING AMINO ACID ALKYL ESTERS AS AMINE COMPONENTS
}

\author{
by \\ FRED WIDMER, KLAUS BREDDAM and JACK T. JOHANSEN \\ Department of Chemistry, Carlsberg Laboratory \\ Gamle Carlsberg Vej 10, DK-2500 Copenhagen Valby
}

Keywords: Enzymatic synthesis, peptide synthesis, amino acid oligomers, carboxypeptidase Y, stereospecificity, high pressure liquid chromatography

\begin{abstract}
Carboxypeptidase $\mathrm{Y}$ catalyzed transacylation reactions between $\mathrm{N}$-protected amino acid methyl esters or peptide methyl esters as initial acyl components and methyl, ethyl, isopropyl or tert.-butyl esters of different $\alpha$ amino acids as amine components are described. The yield of peptide bond formation and the extent of oligomerization of the amine components both depend on the nature of their side chain as well as on the nature of their alkyl ester group. Thus, the methyl esters of all hydrophobic amino acids that were tested oligomerized to various extents (in total product yields ranging from $60-90 \%$ ). On the other hand, the methyl esters of the hydrophilic amino acids did not oligomerize, and were incorporated in yields ranging from $25-50 \%$. Increasing the size of the ester group from methyl, to ethyl, to propyl etc. resulted in a drastic decrease of the degree of oligomerization and - with the exception of glycine - led to reduced coupling yields.
\end{abstract}

\section{INTRODUCTION}

In recent publications $(4,15,16)$ we have demonstrated that carboxypeptidase $Y$ catalyzes the formation of peptide bonds from $\mathrm{N}$-protected amino acid- or peptide esters (acyl components) and amino acids or amino acid amides (amine components). This exopeptidase may thus be- come a useful catalyst for the stepwise enzymatic synthesis of peptides in aqueous phase. We have further shown that CPD-Y catalyzes transpeptidation reactions that can be exploited for peptide synthesis, especially for the exchange of $\mathrm{C}$ terminal amino acids of peptides (3). Since oligomerization of amino acid alkyl esters with

Abbreviations: CPD-Y = carboxypeptidase $\mathrm{Y} ; \mathrm{HPLC}=$ high pressure liquid chromatography; $\mathrm{NaOAc}=$ sodium acetate; Amino acids abbreviated in upper case refer to the L-enantiomer and those in lower case refer to the D-enantiomer. All other abbreviations of amino acids, amino acid derivatives and peptides are according to the guidelines of the IUPAC-IUB Commission on Biochemical Nomenclature (19). 
both endoproteases and esterases is well documented $(2,6,7,8,10,14)$, it was of interest to investigate whether carboxypeptidase Y similarly would catalyze such reactions and if so, whether it would be possible to control the extent of oligomerization and to use amino acid alkyl esters in stepwise synthesis. In the present paper we thus describe experiments designed to explore the potential of this exopeptidase to catalyze reactions between an $\mathrm{N}$-protected amino acid- or peptide methyl ester and an amino acid alkyl ester as shown in equation [1], where $\mathrm{R}_{0}$ stands for peptidyl, $\mathrm{R}_{1}$ for $-\mathrm{CH}_{3},-\mathrm{C}_{2} \mathrm{H}_{5},-\mathrm{C}_{3} \mathrm{H}_{7}$, $\mathrm{CH}\left(\mathrm{CH}_{3}\right)_{2}$ or $-\mathrm{C}\left(\mathrm{CH}_{3}\right)_{3}$ and $\mathrm{AA}$ for an amino acid residue.

$\mathrm{R}_{0}-\mathrm{NH}-\mathrm{AA}_{1}-\mathrm{COOCH}_{3}+\mathrm{NH}_{2}-\mathrm{AA}_{2}-\mathrm{COOR}_{1}$ $\stackrel{\text { CPD-Y }}{\longrightarrow} \mathrm{R}_{0}-\mathrm{NH}-\mathrm{AA}_{1}-\left(\mathrm{AA}_{2}\right)_{\mathrm{n}}-\mathrm{COOR}_{1}+$

$\mathrm{R}_{0}-\mathrm{NH}-\mathrm{AA}_{1}-\left(\mathrm{AA}_{2}\right)_{\mathrm{n}}-\mathrm{COOH}+$

\section{$\mathrm{R}_{0}-\mathrm{NH}-\mathrm{AA}_{1}-\mathrm{COOH}+\mathrm{CH}_{3} \mathrm{OH}$}

The results obtained indicate that synthesis yield and extent of oligomerization critically depend on the structure of the side chain and the structure of the alkyl ester group of the amino acid ester that is used as amine component.

\section{MATERIALS AND METHODS}

\subsection{Materials}

Carboxypeptidase Y from baker's yeast was isolated and used for peptide synthesis as described earlier $(3,4,15)$. $\mathrm{HCl} \cdot \mathrm{H}$-Ala-OMe; $\mathrm{HCl} \cdot \mathrm{H}$-ala-OMe; $\mathrm{HCl} \cdot \mathrm{H}-\mathrm{Val}-\mathrm{OMe} ; \mathrm{HCl} \cdot \mathrm{H}$ $\mathrm{Ser}-\mathrm{OMe} ; \mathrm{HCl} \cdot \mathrm{H}$-Tyr-OMe; $\mathrm{HCl} \cdot \mathrm{H}$-Glu(OMe)$\mathrm{OMe} ; \mathrm{HCl} \cdot \mathrm{H}-\mathrm{Glu}\left(\mathrm{O}^{\prime} \mathrm{Bu}\right)-\mathrm{O}^{t} \mathrm{Bu} ; \mathrm{HCl} \cdot \mathrm{H}$-Asp(OMe)$\mathrm{OMe} ; \mathrm{HCl} \cdot \mathrm{H}-\mathrm{Phe}-\mathrm{OMe} ; \mathrm{HCl} \cdot \mathrm{H}$-Leu-OMe; $\mathrm{HCl} \cdot \mathrm{H}$-Leu-OtBu; $\mathrm{HCl} \cdot \mathrm{H}$-Ile-OMe; $\mathrm{HCl} \cdot \mathrm{H}$ Met-OMe; $\mathrm{HCl} \cdot \mathrm{H}$-Cys(Bzl)-OMe; $\mathrm{HCl} \cdot \mathrm{H}$-Gly$\mathrm{O} B \mathrm{Bu} ; \mathrm{N}$-Benzoyl-alanine methyl ester; $\mathrm{N}$-Acetyl-phenylalanine ethyl ester; N-Acetyl-alanylalanyl-alanine methyl ester and $\mathrm{N}$-Acetyl-alanylalanyl-alanyl-alanine methyl ester were from Bachem AG, Bubendorf, Switzerland. $2 \mathrm{HCl} \cdot \mathrm{H}$ Arg-OMe; $\mathrm{HCl} \cdot \mathrm{H}$-Pro-OMe; $\mathrm{HCl} \cdot \mathrm{H}$-Leu-OEt; glycine, methionine and N-Benzoyl-arginine ethyl ester were from Sigma Chemical Company, St. Louis, USA. $\mathrm{HCl} \cdot \mathrm{H}$-met-OMe; $\mathrm{HCl} \cdot \mathrm{H}$ Lys-OMe; $\mathrm{HCl} \cdot \mathrm{H}$-Met-OEt; Z-alanine methyl ester; Z-alanyl-valine methyl ester; Z-alanylphenylalanine methyl ester and $Z$-alanyl-alanine methyl ester were bought from Vega-Fox Chemicals, Tucson, USA. $\mathrm{HCl} \cdot \mathrm{H}-\mathrm{His}-\mathrm{OMe}$; $\mathrm{H}-$ Thr-OMe; $\mathrm{HCl} \cdot \mathrm{H}-\mathrm{Glu}\left(\mathrm{O}^{\prime} \mathrm{Bu}\right)-\mathrm{OMe} ; \mathrm{HCl} \cdot \mathrm{H}-$ Phe-OEt and $\mathrm{HCl} \cdot \mathrm{H}$-Gly-OMe were from Fluka AG, Buchs, Switzerland. $\mathrm{HCl} \cdot \mathrm{H}-\mathrm{Gly}-$ OEt and analytical grade solvents and reagents were from Merck, Darmstadt, FRG. L-Methionine isopropyl ester hydrochloride was prepared from methionine following the procedure of BRENNER and KOCHER (5) for the racemic amino acid. The hydrochlorides of glycyl isopropyl ester and glycyl n-propyl ester were synthesized from glycine and the corresponding alcohols as described by ABDERHALDEN and SUZUKI (1). All three esters were crystalline compounds with melting points corresponding to the reported values.

\subsection{Methods}

The synthesis reactions were performed on an analytical scale $(2-4 \mathrm{ml})$ using a pH-stat as described earlier $(3,15)$. Aliquots were taken, diluted into a ten-fold excess of $\mathrm{CH}_{3} \mathrm{CN}$ to quench the reaction, and the reactant composition determined by HPLC using $4.5 \times 250 \mathrm{~mm}$ columns and LiChrosorb RP-18 $(10 \mu \mathrm{m})$ resins $(3,15)$. Whenever the quenched sample was inhomogeneous, a clear solution was obtained by the addition of ethanol or water.

Aminolysis and hydrolysis products, not identifiable by cochromatography of authentic samples, were collected and identified by amino acid analysis. The $\mathrm{N}$-protected amino acid methyl esters that were chosen as initial acyl components were normally different from the $\mathrm{N}$ unprotected amino acid esters used as amine components. In this fashion, the extent of oligomerization could directly be determined from the molar ratios of these two amino acids. For two peaks having identical molar ratios, the peptide ester was assumed to be the peak eluting at the higher solvent concentration.

In cases where all reactants of interest had a common chromophore (N-Bz-, N-Cbz-), the per cent composition could be calculated from the integrated peak areas. In experiments where the amino acid ester oligomerized, it was ensured that all products were eluted by comparing the 
peak area of the zero-time sample with the total area of all peaks at latter times. Whenever some sarea«, i.e., some products were missing, the elution conditions were changed until all products were eluted and could be identified.

For the reactions using Ac-( $\mathrm{Ala})_{4}-\mathrm{OMe}$ as acyl component, the yields were determined from quantitative amino acid analysis of completely collected peaks.

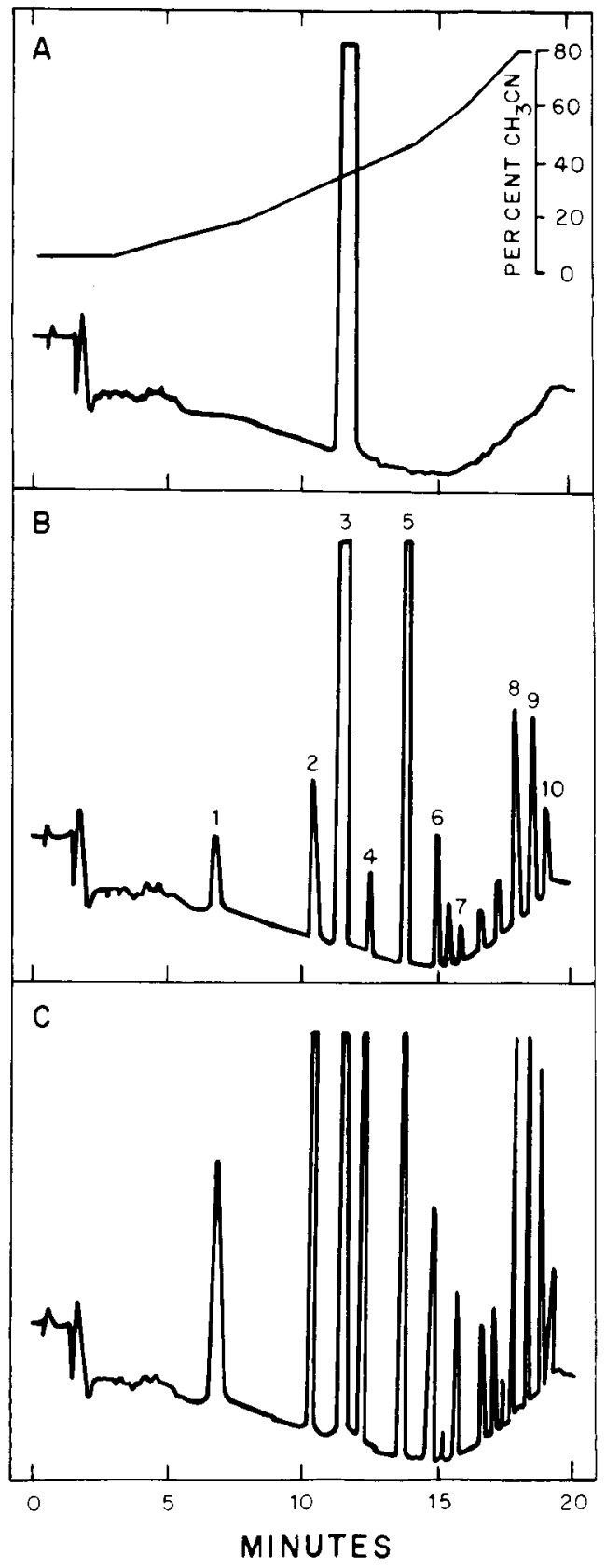

\section{RESULTS}

Having documented CPD-Y catalyzed peptide bond formation between amino acid- or peptide methyl esters as acyl components and amino acids and amino acid amides as amine components $(4,15)$, the present paper describes experiments with amino acid alkyl esters as amine components.

All reactions described here were monitored by HPLC. A representative case of this methodology is given in Figure 1, where the time course of the reaction between $\mathrm{Bz}-\mathrm{Ala}-\mathrm{OMe}$ and $\mathrm{H}$-Met$\mathrm{OMe}$ is illustrated. The identity and the yield of products was determined by amino acid analysis and peak integration as outlined in section 2.2. Table I summarizes the results of a series of such $\mathrm{CPD}-\mathrm{Y}$ catalyzed reactions using Bz-Ala-OMe as initial acyl component and a variety of amino acid methyl esters as amine components. The data indicate that the structure of the side chain of the amino acid methyl esters influences the yield of synthesis and the extent of oligomeriza-

Figure 1. HPLC chromatograms of peptides formed by CPD-Y catalyzed oligomerization of $\mathrm{H}-\mathrm{Met}-\mathrm{OMe}$ using $\mathrm{Bz}$-Ala-OMe as the initial substrate.

Experimental conditions are given in Table II. At 0,2 and $9 \mathrm{~min}$ (Figures IA, 1B, IC) $100 \mu$ aliquots were quenched into $1 \mathrm{ml} \mathrm{CH}{ }_{3} \mathrm{CN}$ to which were added (after $\sim 3 \mathrm{~min}$ ) $2 \mathrm{ml} 50 \%$ ethanol in order to dissolve all reactants; $20 \mu \mathrm{l}$ of this mixture was separated on a $4.5 \times 250 \mathrm{~mm}$ column of LiChrosorb RP-18 $(10 \mu \mathrm{m})$ using a Hewlett-Packard Model 1084 Liquid Chromatograph. The eluants were: $\mathrm{A}=$ $50 \mathrm{~mm}-\mathrm{NaOAc}, \mathrm{pH} 4.0 ; \mathrm{B}=100 \% \mathrm{CH}_{3} \mathrm{CN} \cdot \mathrm{S}$. The gradient used went from $6 \%$ to $80 \% \mathrm{~B}$ in $18 \mathrm{~min}$ as indicated in Figure 1A. Other chromatographic parameters were as follows. Temperatures: oven 47 ${ }^{\circ} \mathrm{C}$, solvent A $70{ }^{\circ} \mathrm{C}$, solvent B $47^{\circ} \mathrm{C}$. Flow: 3 $\mathrm{ml} \cdot \mathrm{min}^{-1}$. Column pressure: 190 at. Chart speed: $0.5 \mathrm{~cm} \cdot \mathrm{min}^{-1}$. Ordinate shows absorbance at 254 $\mathrm{nm}$. By cochromatography with authentic samples and by collection of peaks and amino acid hydrolysis the following peak assignments were made: $1=\mathrm{Bz}$ Ala-OH; 2 = Bz-Ala-Met-OH; 3 = Bz-Ala-OMe; 4 $=\mathrm{Bz}-\mathrm{Ala}-(\mathrm{Met})_{2}-\mathrm{OH} ; 5=\mathrm{Bz}-\mathrm{Ala}-(\mathrm{Met})_{2}-\mathrm{OMe} ; 6$ $=\mathrm{Bz}-\mathrm{Ala}-(\mathrm{Met})_{3}-\mathrm{OH} ; 7=\mathrm{Bz}-\mathrm{Ala}-(\mathrm{Met})_{4}-\mathrm{OH} ; 8=$ Bz-Ala-(Met) $)_{5}-\mathrm{OH} ; 9=\mathrm{Bz}$-Ala-(Met) ${ }_{5}-\mathrm{OMe} ; 10=$ Bz-Ala-(Met) $)_{4}-\mathrm{OMe}$. The fact that 9 elutes before 10 , may indicate a secondary structure (chain coiling) of Bz-Ala-(Met) $)_{5}$-OMe which renders it less hydrophobic than Bz-Ala-(Met) ${ }_{4}-\mathrm{OMe}$. 
Table I

CPD-Y catalyzed peptide synthesis using Bz-Ala-OMe as initial acyl component and amino acid methyl esters as amine components.a)

\begin{tabular}{|c|c|c|c|c|}
\hline Amine componentsb) & $\begin{array}{l}\text { Reaction } \\
\text { time (min.)c) }\end{array}$ & Aminolysis products & $\begin{array}{l}\text { Individual product } \\
\text { yields, \%c) }\end{array}$ & $\begin{array}{l}\text { Total } \\
\text { yield, \%d) }\end{array}$ \\
\hline H-Gly-OMe & 10 & $\begin{array}{l}\text { Bz-Ala-Gly-OH } \\
\text { Bz-Ala-Gly-OMe }\end{array}$ & $\begin{array}{r}5 \\
45\end{array}$ & 50 \\
\hline $\mathrm{H}$-Ser-OMe & 20 & $\begin{array}{l}\text { Bz-Ala-Ser-OH } \\
\text { Bz-Ala-Ser-OMe }\end{array}$ & $\begin{array}{r}5 \\
45\end{array}$ & 50 \\
\hline H-Thr-OMe & 15 & $\begin{array}{l}\text { Bz-Ala-Thr-OH } \\
\text { Bz-Ala-Thr-OMe }\end{array}$ & $\begin{array}{l}10 \\
35\end{array}$ & 45 \\
\hline H-Lys-OMe & 15 & $\begin{array}{l}\text { Bz-Ala-Lys-OH } \\
\text { Bz-Ala-Lys-OMe } \\
\text { Bz-Ala-(Lys) } 2-O H \\
\text { Bz-Ala-(Lys) }-\mathrm{OMe}\end{array}$ & $\begin{array}{r}35 \\
15 \\
15 \\
5\end{array}$ & 70 \\
\hline $\mathrm{H}-\mathrm{Arg}-\mathrm{OMe}$ & 30 & $\begin{array}{l}\text { Bz-Ala-Arg-OH } \\
\text { Bz-Ala-Arg-OMe }\end{array}$ & $\begin{array}{l}30 \\
10\end{array}$ & 40 \\
\hline H-His-OMe & 10 & $\begin{array}{l}\text { Bz-Ala-His-OH } \\
\text { Bz-Ala-His-OMe }\end{array}$ & $\begin{array}{r}8 \\
17\end{array}$ & 25 \\
\hline H-Pro-OMe & 10 & --- & & 0 \\
\hline H-Tyr-OMe & 15 & $\begin{array}{l}\text { Bz-Ala-Tyr-OH } \\
\text { Bz-Ala-Tyr-OMe }\end{array}$ & $\begin{array}{r}20 \\
5\end{array}$ & 25 \\
\hline $\mathrm{H}-\mathrm{Cys}(\mathrm{Bzl})-\mathrm{OMe}$ & $20 \mathrm{e})$ & $\begin{array}{l}\mathrm{Bz}-\mathrm{Ala}-\mathrm{Cys}(\mathrm{Bzl})-\mathrm{OH} \\
\text { Bz-Ala-(Cys(Bzil) })_{2}-\mathrm{OH}\end{array}$ & $\begin{array}{l}50 \\
30\end{array}$ & $80 \%$ \\
\hline H-Asp(OMe)-OMe & 15 & $\begin{array}{l}\text { Bz-Ala-Asp(OMe)-OH } \\
\text { Bz-Ala-Asp(OMe)-OMe } \\
\text { Bz-Ala-(Asp(OMe) })_{2}-\mathrm{OH} \\
\text { Bz-Ala-(Asp }(\mathrm{OMe}))_{2}-\mathrm{OMe}\end{array}$ & $\begin{array}{r}12 \\
30 \\
9 \\
9\end{array}$ & $60 f)$ \\
\hline $\mathrm{H}$-Glu(OMe)-OMe & 15 & $\begin{array}{l}\text { Bz-Ala-Glu(OMe)-OH } \\
\text { Bz-Ala-Glu(OMe)-OMe } \\
\text { Bz-Ala-(Glu(OMe) })_{2}-\mathrm{OH} \\
\text { Bz-Ala-(Glu(OMe) })_{2}-\mathrm{OMe} \\
\text { Bz-Ala-(Glu(OMe) })_{3}-\mathrm{OH} \\
\text { Bz-Ala-(Glu(OMe) })_{3}-\mathrm{OMe}\end{array}$ & $\begin{array}{r}30 \\
15 \\
12 \\
12 \\
8 \\
8\end{array}$ & 85 ) \\
\hline H-Ala-OMe & 10 & $\begin{array}{l}\text { Bz-Ala-Ala-OH } \\
\text { Bz-Ala-(Ala) })_{2}-\mathrm{OH} \\
\text { Bz-Ala-(Ala })_{3}-\mathrm{OH} \\
\text { Bz-Ala-(Ala })_{4}-\mathrm{OH}\end{array}$ & $\begin{array}{r}30 \\
21 \\
16 \\
8\end{array}$ & $75 f)$ \\
\hline H-Val-OMe & 20 & $\begin{array}{l}\text { Bz-Ala-Val-OH } \\
\text { Bz-Ala-(Val) })_{2}-\mathrm{OH}\end{array}$ & $\begin{array}{l}60 \\
15\end{array}$ & $751)$ \\
\hline H-Ile-OMe & 25 & $\begin{array}{l}\text { Bz-Ala-Ile-OH } \\
\text { Bz-Ala-Ile-OMe } \\
\text { Bz-Ala-(Ile) })_{2}-\mathrm{OH} \\
\text { Bz-Ala-(Ile) })_{2}-\mathrm{OMe}\end{array}$ & $\begin{array}{l}12 \\
50 \\
10 \\
18\end{array}$ & 901) \\
\hline H-Leu-OMe & 20 & $\begin{array}{l}\text { Bz-Ala-Leu-OH } \\
\text { Bz-Ala-Leu-OMe } \\
\text { Bz-Ala-(Leu) })_{2}-\mathrm{OH} \\
\text { Bz-Ala-(Leu) })_{2}-\mathrm{OMe} \\
\text { Bz-Ala-(Leu) } 3-\mathrm{OH}\end{array}$ & $\begin{array}{r}22 \\
5 \\
22 \\
4 \\
22\end{array}$ & $75 f$ \\
\hline H-Phe-OMe & 20 & $\begin{array}{l}\text { Bz-Ala-Phe-OH } \\
\text { Bz-Ala-Phe-OMe } \\
\text { Bz-Ala-(Phe) }{ }_{2}-\mathrm{OH}\end{array}$ & $\begin{array}{r}36 \\
8 \\
20\end{array}$ & \\
\hline
\end{tabular}




\begin{tabular}{|c|c|c|c|c|}
\hline Amine components ${ }^{b}$ ) & $\begin{array}{l}\text { Reaction } \\
\text { time (min.)c) }\end{array}$ & Aminolysis products & $\begin{array}{l}\text { Individual product } \\
\text { yields, \% } \%\end{array}$ & $\begin{array}{l}\text { Total } \\
\text { yield, } \% d \text { ) }\end{array}$ \\
\hline & & $\begin{array}{l}\mathrm{Bz}-\mathrm{Ala}-(\mathrm{Phe})_{2}-\mathrm{OMe} \\
\mathrm{Bz}-\mathrm{Ala}-(\mathrm{Phe})_{3}-\mathrm{OH}\end{array}$ & $\begin{array}{r}4 \\
12\end{array}$ & 800 \\
\hline H-Met-OMe & 15 & $\begin{array}{l}\mathrm{Bz}-\mathrm{Ala}-\mathrm{Met}-\mathrm{OH} \\
\mathrm{Bz}-\mathrm{Ala}-(\mathrm{Met})_{2}-\mathrm{OH} \\
\mathrm{Bz}-\mathrm{Ala}-(\mathrm{Met})_{2}-\mathrm{OMe} \\
\mathrm{Bz}-\mathrm{Ala}-(\mathrm{Met})_{3}-\mathrm{OH} \\
\mathrm{Bz}-\mathrm{Ala}-(\mathrm{Met})_{4}-\mathrm{OH} \\
\mathrm{Bz}-\mathrm{Ala}-(\mathrm{Met})_{4}-\mathrm{OMe} \\
\mathrm{Bz}-\mathrm{Ala}-(\mathrm{Met})_{5}-\mathrm{OH} \\
\mathrm{Bz}-\mathrm{Ala}-(\mathrm{Met})_{5}-\mathrm{OMe}\end{array}$ & $\begin{array}{r}21 \\
15 \\
14 \\
5 \\
4 \\
7 \\
11 \\
13\end{array}$ & $90 f)$ \\
\hline
\end{tabular}

a) The reactions $(2.5 \mathrm{ml}$ ) were performed in a $\mathrm{pH}$-stat and evaluated by HPLC as described in section 2 (cf. also Figure 1). Conditions: $50 \mathrm{~mm} \mathrm{Bz}$-Ala-OMe, 0.1 $\mathrm{m}$-KCl, I mm-EDTA, $10 \% \mathrm{CH} 3 \mathrm{OH}, \mathrm{pH} 9.6,20-25^{\circ} \mathrm{C}, 8 \mu \mathrm{M}$ CPD-Y.

b) H-Ser-OMe was 1.0 m. H-Leu-OMe, H-lle-OMe, H-Phe-OMe, H-Met-OMe, H-Cys(Bzl)-OMe were 0.2 м; the latter ester was only partially dissolved. All other esters were $0.5 \mathrm{M}$.

c) Reaction time for which the individual product yields are reported. At these times more than $90 \%$ of $\mathrm{Bz}$-AlaOMe had been converted to products. With time, the relative composition of the products changed, but only insignificant amounts $(<5 \%)$ of new, higher oligomers were formed.

d) This corresponds to the sum of all aminolysis products and indicates the percentage of Bz-Ala-OMe that was converted to peptides as opposed to $\mathrm{Bz}-\mathrm{Ala}-\mathrm{OH}$, i.e., it is the aminolysis yield for the reaction between $\mathrm{Bz}-\mathrm{Ala}$ OMe and H-Gly-OMe, H-Ser-OMe etc.

e) At this time, $60 \%$ of Bz-Ala-OMe was still unconverted as its rate of conversion was strongly inhibited by $\mathrm{H}$ Cys(Bzl)-OMe.

f) Some products partially precipitated.

tion. The methyl esters of the hydrophilic amino acids are incorporated in lower yields - and result in less oligomerization - than the methyl esters of the hydrophobic amino acids.

The stereospecificity of CPD-Y catalyzed peptide bond formation was investigated with respect to D- and L-amino acid methyl esters. It was found (Table II) that D-methionine methyl ester is not incorporated al all. This is clearly illustrated by the two HPLC chromatograms (Figures 2A \& 2D) of the products formed in the reaction of $\mathrm{Bz}-\mathrm{Ala}-\mathrm{OMe}$ with $\mathrm{H}-\mathrm{Met}-\mathrm{OMe}$ and

\section{Table II}

Stereospecificity of CPD-Y catalyzed peptide bond formation with respect to D- and L-amino acid methyl esters.a)

\begin{tabular}{lllc}
\hline Initial acyl component & Amine component & Reaction products formedb) & Yield, \% \\
\hline Bz-Ala-OMe & H-Met-OMe & Bz-Ala-OH & 10 \\
& & Bz-Ala-(Met) $)_{n}-\mathrm{OX}$ & 90 \\
& H-met-OMe & Bz-Ala-OH & 100 \\
Ac-Phe-OEt & H-Ala-OMe & Ac-Phe-OH & 40 \\
& & Ac-Phe-(Ala) $)_{n}-\mathrm{OX}$ & 60 \\
& H-ala-OMe & Ac-Phe-OH & 100 \\
\hline
\end{tabular}

a) Conditions: $0.1 \mathrm{~m}-\mathrm{KCl}, 1 \mathrm{~mm}-\mathrm{EDTA}, 10 \% \mathrm{CH}_{3} \mathrm{OH}$, pH 9.5, 20-25 ${ }^{\circ} \mathrm{C}$. Both acyl components were $50 \mathrm{~mm}$, all amine components were $0.5 \mathrm{M}$. CPD-Y was $4 \mu \mathrm{M}$ for the Bz-Ala-OMe reactions and $8 \mu \mathrm{M}$ for the ones with Ac-Phe-OEt. The reactions were stopped after $20 \mathrm{~min}$. and the reactant composition determined by HPLC.

b) $\mathrm{X}=-\mathrm{H}$ or $-\mathrm{CH}_{3}$. The index $\mathrm{n}$ indicates the extent of oligomerization. For $\mathrm{H}-\mathrm{Met}-\mathrm{OMe}, \mathrm{n}=1,2,3,4,5$ and for H-Ala-OMe, $n=1,2$. 


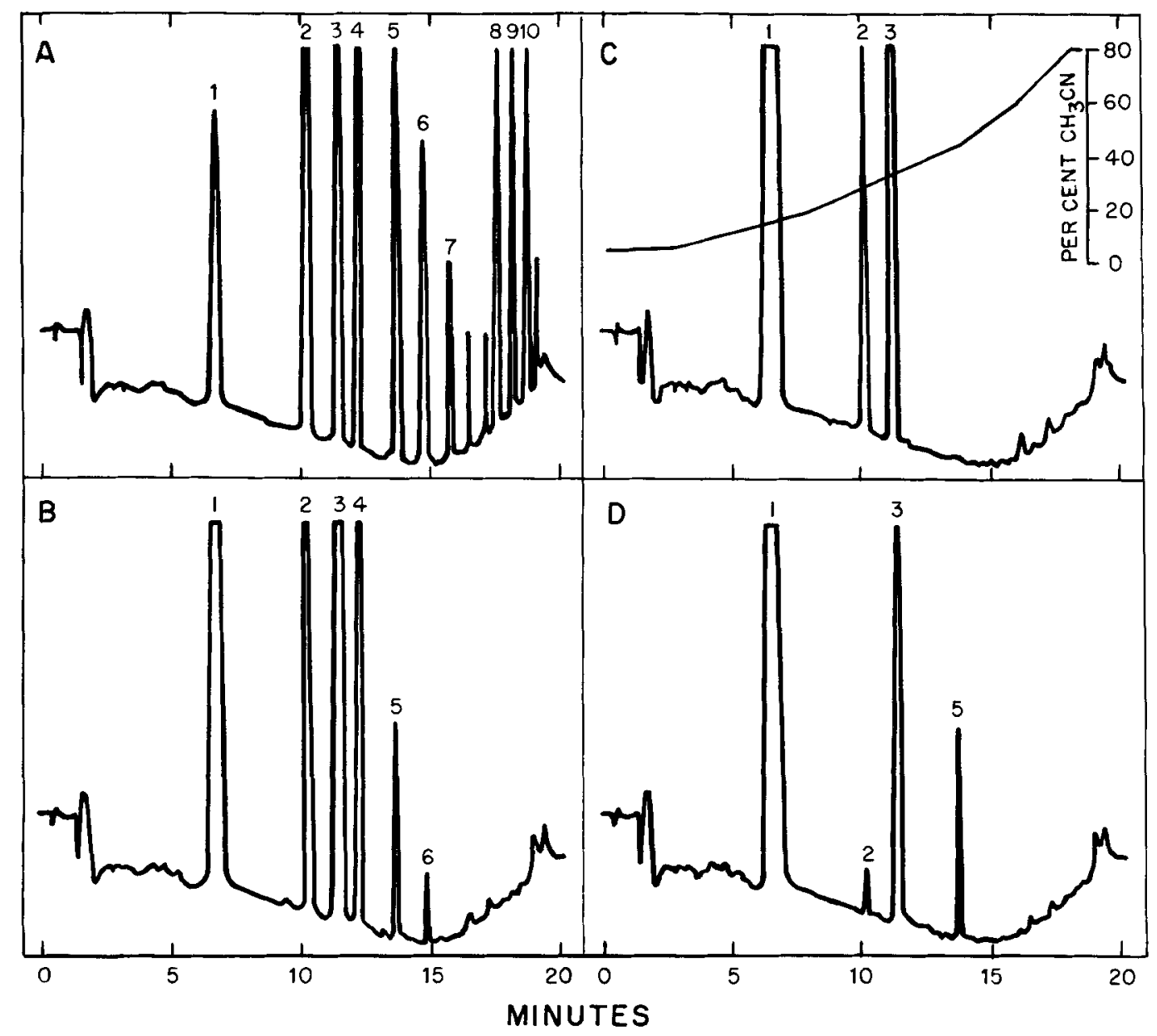

Figure 2. HPLC chromatograms of peptides formed by CPD-Y catalyzed reactions between Bz-Ala-OMe and HMet-OMe (Figure 2A), H-Met-OEt (Figure 2B), H-Met-OiPr (Figure 2C) and H-met-OMe (Figure 2D).

Experimental conditions are given in Tables I and II. The chromatograms shown were all performed on samples taken $9 \mathrm{~min}$ after CPD-Y had been added to the mixture of $\mathrm{Bz}$-Ala-OMe and methionine ester. For a zero-time sample cf. Figure 1A. Chromatographic conditions and peak assignments are as in Figure 1.

$\mathrm{H}$-met-OMe. While the L-methionine methyl ester resulted in extensive oligomerization, the almost exclusively and rapidly formed product with the D-ester was Bz-Ala-OH. Similar stereospecificity could also be documented for the reactions of $D$ - and L-alanine methyl ester with $\mathrm{N}$-acetyl-phenylalanine ethyl ester.

The influence of the size of the alkyl ester group of the amine component on synthesis yields and degree of oligomerization was examined using as initial acyl component Bz-Ala-OMe and as amine components the methyl, ethyl, propyl, isopropyl and tert.-butyl esters of glycine, alanine, leucine, glutamic acid and methionine, respectively. The results are listed in Table III and indicate that the yields of the reaction with Bz-Ala-OMe, as well as the extent of oligomerization, decrease with increasing size of the ester group. With methionine, for example, an increase of the size of the ester group from methyl to ethyl to isopropyl resulted in a decrease of oligomerization from $\mathrm{n}=1,2,3,4$, 5 to $\mathrm{n}=1$, and in an increase in the formation of Bz-Ala-OH (the primary hydrolysis product) 
F. WIDMer et al.: Peptide synthesis

Table III

CPD-Y catalyzed peptide synthesis using Bz-Ala-OMe as initial acyl component and amino acid alkyl esters as amine component.a)

\begin{tabular}{|c|c|c|c|}
\hline Amine componentsb) & Aminolysis products formed & nc) & Total yield, \%d) \\
\hline H-Gly-OMe & Bz-Ala-Gly-OH, Bz-Ala-Gly-OMe & 1 & 50 \\
\hline H-Gly-OEt & Bz-Ala- $(\mathrm{Gly})_{\mathrm{n}}-\mathrm{OH}, \mathrm{Bz}-\mathrm{Ala}-(\mathrm{Gly})_{\mathrm{n}}-\mathrm{OEt}$ & 1,2 & 95 \\
\hline $\mathrm{H}-\mathrm{Gly}-\mathrm{OnPr}$ & $\mathrm{Bz}-\mathrm{Ala}-(\mathrm{Gly})_{\mathrm{n}}-\mathrm{OH}, \mathrm{Bz}-\mathrm{Ala}-(\mathrm{Gly})_{\mathrm{n}} \mathrm{O} \mathrm{OPr}$ & $1,(2)$ & $85 \mathrm{e}) \mathrm{f}$ \\
\hline H-Gly-OiPr & Bz-Ala-Gly-OH, Bz-Ala-Gly-OiPr & 1 & $90 \mathrm{e})$ \\
\hline $\mathrm{H}-\mathrm{Gly}-\mathrm{O} \mathrm{tBu}$ & $\mathrm{Bz}$-Ala-Gly-OH, Bz-Ala-Gly-OtBu & 1 & $70 \mathrm{e}) \mathrm{f}$ \\
\hline $\mathrm{H}$-Ala-OMe & $\mathrm{Bz}-\mathrm{Ala}-(\mathrm{Ala})_{\mathrm{n}}-\mathrm{OH}, \mathrm{Bz}-\mathrm{Ala}-(\mathrm{Ala})_{\mathrm{n}}-\mathrm{OMe}$ & $1,2,3,4$ & $65 f)$ \\
\hline $\mathrm{H}$-Ala-OEt & Bz-Ala-(Ala) $)_{n}-O H$, Bz-Ala- $(\text { Ala })_{n}-O E t$ & $1,2,(3),(4)$ & $35 f)$ \\
\hline $\mathrm{H}-\mathrm{Ala}-\mathrm{O}$ Bu & Bz-Ala-Ala-OH, Bz-Ala-Ala-OtBu & 1 & $10 \mathrm{e})$ \\
\hline H-Leu-OMe & $\mathrm{Bz}-\mathrm{Ala}-(\mathrm{Leu})_{\mathrm{n}}-\mathrm{OH}, \mathrm{Bz}-\mathrm{Ala}-(\mathrm{Leu})_{\mathrm{n}}-\mathrm{OMe}$ & $1,2,3$ & $75 f)$ \\
\hline H-Leu-OEt & $\mathrm{Bz}-\mathrm{Ala}-(\mathrm{Leu})_{\mathrm{n}}-\mathrm{OH}, \mathrm{Bz}-\mathrm{Ala}-(\mathrm{Leu})_{\mathrm{n}}-\mathrm{OEt}$ & $1,(2)$ & $40 ?$ \\
\hline $\mathrm{H}-\mathrm{Leu}-\mathrm{O} \mathrm{tBu}$ & $---\quad \quad---$ & & 0 \\
\hline $\mathrm{H}-\mathrm{Glu}(\mathrm{O} \mathrm{tBu})-\mathrm{OMe}$ & $\mathrm{Bz}-\mathrm{Ala}-\mathrm{Glu}(\mathrm{O} t \mathrm{Bu})-\mathrm{OH}, \mathrm{Bz}-\mathrm{Ala}-\mathrm{Glu}(\mathrm{O} \mathrm{tBu})-\mathrm{OMe}$ & 1 & $35 f)$ \\
\hline $\mathrm{H}-\mathrm{Glu}(\mathrm{O}+\mathrm{Bu})-\mathrm{O} \mathrm{tBu}$ & $---\quad \quad---$ & & 0 \\
\hline H-Met-OMe & Bz-Ala-(Met) $)_{n}-\mathrm{OH}, \mathrm{Bz}-\mathrm{Ala}-(\mathrm{Met})_{\mathrm{n}}-\mathrm{OMe}$ & $1,2,3,4,5$ & 900 \\
\hline H-Met-OEt & $\mathrm{Bz}$-Ala-(Met $)_{\mathrm{n}}-\mathrm{OH}, \mathrm{Bz}-\mathrm{Ala}-(\mathrm{Met})_{\mathrm{n}}-\mathrm{OEt}$ & $1,(2)$ & $40 f$ \\
\hline H-Met-OiPr & Bz-Ala-Met-OH & 1 & 10 \\
\hline
\end{tabular}

a) As in Table I, with the exception that the reaction time varied from 5-60 min. depending on the degree of inhibition of Bz-Ala-OMe conversion by the different amino acid esters.

b) The glycine- and alanine esters were $0.5 \mathrm{~m}$, all others were $0.2 \mathrm{~m}$.

c) $\mathrm{n}$ indicates the degree of oligomerization observed under the given reaction conditions. A number in brackets indicates that the corresponding oligomer constituted less than $5 \%$ of all aminolysis products.

d) The total yield indicates the percentage of $\mathrm{Bz}$-Ala-OMe that was converted to peptides and peptide esters as opposed to Bz-Ala-OH.

e) Here, the peptide ester accumulated as the major product, i.e., at the time of complete Bz-Ala-OMe conversion, the peptide esters constituted $>80 \%$ of the aminolysis products formed.

f) Some products partially precipitated.

from $10 \%$ to $90 \%$. This dependence of product formation on the size of the ester group of the amine component is further documented by the HPLC chromatograms in Figures 2A, 2B and $2 C$. Similar observations were made for other amino acid esters, and it is clear that - with the exception of glycine esters - a small increase in the size of the ester group of the amine component significantly affects the reaction course.

Table IV lists results of reactions between $\mathrm{N}$ protected peptide methyl esters and some amino acid esters that did not oligomerize when Bz-AlaOMe was used as acyl component. The yields of incorporation - again with the exception of glycine - are rather low, but it should be noted that reaction conditions were not optimized.

\section{DISCUSSION}

In the course of our initial studies on the use of carboxypeptidase $\mathrm{Y}$ in peptide synthesis (4, 15) it had become evident that amino acid amides were incorporated in generally much higher yields than amino acids. This difference was partly explained by considering that the $\mathrm{pK}_{\mathrm{a}}$ of the $\alpha$-amino group of the free amino acids is approx. 9.6 while it is approx. 8.2 for the amino acid amides, a fact which would render the latter better nucleophiles at $\mathrm{pH} 9.5$ where the reactions normally are carried out. The diverse yields could also be explained by postulating a difference in the mode in which the amides and the free acids bind to the enzyme prior to the formation of a peptide bond. The amides evidently bind in a mode that results in the 
Table IV

CPD-Y catalyzed peptide synthesis using $\mathrm{N}$-protected dipeptide methyl esters as acyl components and amino acid alkyl esters as amine components.a)

\begin{tabular}{|c|c|c|c|}
\hline Acyl components & Amine components & Aminolysis productsb) & Yield, \%c) \\
\hline Z-Ala-Ala-OMe & $\begin{array}{l}\text { H-Leu-OEt } \\
\text { H-His-OMe } \\
\text { H-Gly-OiPr } \\
\text { H-Gly-OtBu }\end{array}$ & $\begin{array}{l}\text { Z-Ala-Ala-Leu-OH } \\
\text { Z-Ala-Ala-His-OH } \\
\text { Z-Ala-Ala-Gly-OiPr } \\
\text { Z-Ala-Ala-Gly-OtBu }\end{array}$ & $\begin{array}{l}15 \\
15 \\
80 \mathrm{e}) \\
90 \mathrm{e})\end{array}$ \\
\hline Z-Ala-Val-OMed) & $\begin{array}{l}\text { H-Leu-OEt } \\
\text { H-His-OMe } \\
\text { H-Thr-OMe } \\
\text { H-Gly-OtBu }\end{array}$ & $\begin{array}{l}--- \\
\text { Z-Ala-Val-His-OH } \\
\text { Z-Ala-Val-Thr-OH } \\
\text { Z-Ala-Val-Gly-OtBu }\end{array}$ & $\begin{array}{l}0 \\
10 \\
20 \\
80 \mathrm{e})\end{array}$ \\
\hline Z-Ala-Phe-OMed) & $\begin{array}{l}\text { H-Leu-OEt } \\
\text { H-His-OMe } \\
\text { H-Thr-OMe } \\
\text { H-Gly-OiPr }\end{array}$ & $\begin{array}{l}\text { Z-Ala-Phe-Leu-OH } \\
\text { Z-Ala-Phe-His-OH } \\
\text { Z-Ala-Phe-Thr-OH } \\
\text { Z-Ala-Phe-Gly-OiPr }\end{array}$ & $\begin{array}{l}10 \\
10 \\
15 \\
80 \mathrm{e})\end{array}$ \\
\hline $\mathrm{Ac}-(\mathrm{Ala})_{4}-\mathrm{OMe}$ & $\begin{array}{l}\text { H-Leu-OEt } \\
\text { H-His-OMe } \\
\text { H-Gly-OtBu }\end{array}$ & $\begin{array}{l}\mathrm{Ac}-(\mathrm{Ala})_{4}-\mathrm{Leu}-\mathrm{OH} \\
\mathrm{Ac}-(\mathrm{Ala})_{4}-\mathrm{His}-\mathrm{OH} \\
\mathrm{Ac}-(\mathrm{Ala})_{4}-\mathrm{Gly}-\mathrm{O} \mathrm{Bu}\end{array}$ & $\begin{array}{l}15 \\
20 \\
601\end{array}$ \\
\hline
\end{tabular}

a) Conditions: $10 \mathrm{~mm}$ substrate, $0.1 \mathrm{M}-\mathrm{KCl}, 1 \mathrm{~mm}-\mathrm{EDTA}, 10 \% \mathrm{CH}_{3} \mathrm{OH}, \mathrm{pH} 9.5,20-25^{\circ} \mathrm{C}$. CPD-Y $=7 \mu \mathrm{M}$ for $\mathrm{Z}$-substrates and $2 \mu \mathrm{M}$ for $\mathrm{Ac}-(\mathrm{Ala})_{4}-\mathrm{OMe}$. Amine components were $0.25 \mathrm{M}$.

b) Reactant composition was evaluated by HPLC and followed up to $30 \mathrm{~min}$. Oligomerization was not observed in any case.

c) The yields given are those observed at $20 \mathrm{~min}$. The remainder of the acyl component was converted by hydrolysis to e.g. Z-Ala-Ala-OH etc.

d) These acyl components were incompletely dissolved.

e) Product partially precipitated.

f) Yield at $5 \mathrm{~min}$. With time, the ester is hydrolyzed.

partitioning of the acyl-enzyme strongly in favor of aminolysis rather than hydrolysis. A strategy for CPD-Y catalyzed peptide synthesis was thus adopted (cf. Scheme 1) where an amino acid amide is coupled to a peptide methyl ester to form a peptide amide. This step is followed by CPD-Y catalyzed deamidation and chemical esterification to produce a methyl ester that functions as the acyl-component for the consequent coupling step. This procedure has been

$$
\begin{aligned}
& \mathrm{R}-\mathrm{NH}-\mathrm{AA}_{1}-\mathrm{OMe}+\mathrm{NH}_{2}-\mathrm{AA}_{2}-\mathrm{CONH}_{2} \quad \stackrel{\mathrm{CPD}-\mathrm{Y}}{-\cdots+} \mathrm{R}-\mathrm{NH}-\mathrm{AA}_{1}-\mathrm{AA}_{2}-\mathrm{CONH}_{2}
\end{aligned}
$$

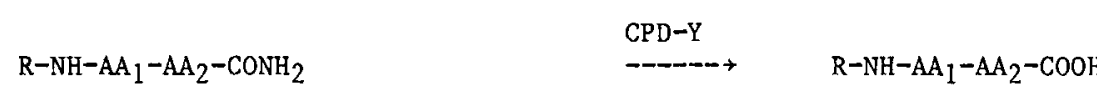

$$
\begin{aligned}
& \mathrm{R}-\mathrm{NH}-\mathrm{AA}_{1}-\mathrm{AA}_{2}-\mathrm{COOH} \quad \mathrm{R}-\mathrm{NH}-\mathrm{AA}_{1}-\mathrm{AA}_{2}-\mathrm{COOCH}_{3}
\end{aligned}
$$

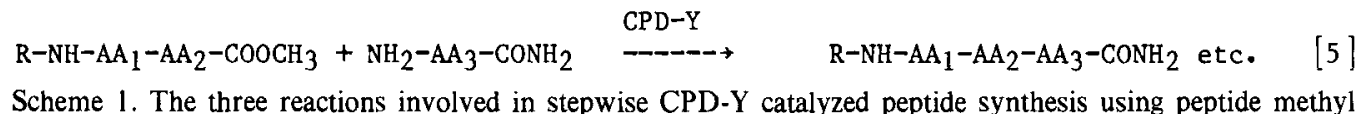
esters as acyl components and amino acid amides as amine components. $\mathrm{R}=$ peptidyl, protecting group. $\mathrm{AA}=$ amino acid residue. 
successfully employed for the synthesis of metenkephalin (16).

Since amino acid methyl esters share with amino acid amides properties which distinguish them from amino acids, i.e., a $\mathrm{pK}_{\mathrm{a}}$ of the $\alpha$ amino group of 8.2-8.5 and a neutral $C$ terminal, it was of interest whether these esters would be incorporated in as high yields as the amides. In addition, it was of interest whether since the synthesis product would be a peptide methyl ester - a formation of amino acid oligomers would result, and if so, would it be possible to control the extent of such oligomerization? The answers to these questions were important for the evaluation of the possible use of amino acid esters in stepwise synthesis whereby the deamidation step in the synthesis procedure shown in Scheme 1 could be eliminated.

The results obtained with $\mathrm{Bz}-\mathrm{Ala}-\mathrm{OMe}$ as the initial acyl component and a series of amino acid methyl esters as amine components indicated that the amino acid methyl esters are not generally coupled to Bz-Ala- in as high yields as had been observed for amino acid amides (15, 17). While the difference in yield between the amide and the methyl ester was not very large for the hydrophobic amino acids (80-95\% with amides versus $65-90 \%$ with esters), it was significant for the hydrophilic ones, e.g., $90 \%$ with serine amide versus $50 \%$ with serine methyl ester and $85 \%$ with histidine amide versus $25 \%$ with histidine methyl ester. These data demonstrate; that for optimal aminolysis yields it is not sufficient for the amine component to have a neutral $\mathrm{C}$-terminal and $\mathrm{a} \mathrm{pK}_{\mathrm{a}}$ of the $\alpha$-amino group below the $\mathrm{pH}$ where the reactions are carried out, viz. $\mathrm{pH}$ 9.5. Unique structural features of the amide function of amino acid amides are apparently responsible for the high yields observed with this type of amine component.

Concerning the question of oligomerization, the above series of experiments indicates that the methyl esters of the hydrophilic amino acids undergo little or no oligomerization, while the methyl esters of the hydrophobic amino acids do so to various extents, the highest one $(n=1,2$, $3,4,5$ ) being observed for methionine methyl ester. These results are in agreement with the above mentioned generally lower coupling yields of the methyl esters of the hydrophilic amino acids with the initial acyl-component Bz-AlaOMe. One would indeed expect a higher degree of oligomerization for H-Met-OMe (where the yield for the first step was $90 \%$ ) than for H-SerOMe (first step yield was $50 \%$ ) since in every following elongation step only $10 \%$ of each oligomer of Bz-Ala-(Met) ${ }_{n}$-OMe would be converted to Bz-Ala-(Met) $)_{n}-\mathrm{OH}$ while $90 \%$ would be converted to Bz-Ala-(Met $)_{n+1}-\mathrm{OMe}$, the substrate needed to form higher oligomers. However, by this argumentation some oligomerization would be expected for $\mathrm{H}$-Ser-OMe since the initial coupling yield was $50 \%$. An additional explanation for the observed difference between hydrophobic and hydrophilic amino acids is suggested by the fact that the aminolysis/ hydrolysis ratio depends on the side-chain structure of the acyl-donating amino acid (4). Thus, when using $\mathrm{H}-\mathrm{His}-\mathrm{OMe}$ or $\mathrm{H}-\mathrm{Gly}-\mathrm{OMe}$ for example, the substrate for the second elongation step is Bz-Ala-His-OMe or Bz-AlaGly-OMe, whereas with H-Leu-OMe or H-Met$\mathrm{OMe}$ it is Bz-Ala-Leu-OMe or Bz-Ala-Met-OMe According to the data obtained earlier (4), the acyl-enzyme of Bz-Ala-His-OMe (or other peptides with a hydrophilic amino acid in the ultimate position) will be partitioned more in favor of hydrolysis than the acyl-enzyme of Bz-Ala-LeuOMe (or other peptides with a hydrophobic amino acid in the ultimate position). Accordingly, significant oligomerization would only be expected for the methyl esters of the hydrophobic amino acids. However, the structure of the ultimate amino acid residue is not the sole determinant of the aminolysis/hydrolysis ratios when amino acid esters are used as amine components. It is the entire structure of the acylcomponent (including the structure of the ester leaving group) that needs to be considered. This is clearly evident from the fact that $\mathrm{H}$-Gly-OMe did not oligomerize with $\mathrm{Bz}-\mathrm{Ala}-\mathrm{OMe}$ as initial acyl-component whereas H-Gly-OEt did. Such peculiarities may be exploited to obtain higher yields when designing a strategy for peptide synthesis, as was demonstrated in the synthesis of met-enkephalin (16).

In addition to the partitioning of the acylenzyme between aminolysis and hydrolysis in each individual elongation step, the solubility of the intermediate peptide methyl esters might also 
limit the extent of oligomerization. However, since the equilibrium of the solutes between the solid-phase and the liquid phase will be rapid under stirred conditions, and since longer peptide esters can be expected to bind more tightly to the enzyme, this factor is probably less restricting than those determining the individual coupling yields. Indeed, although the products often precipitated (e.g., Bz-Ala-(Leu) $)_{n}-\mathrm{OMe}$ and $\mathrm{Bz}$ Ala-(Met) ${ }_{n}-\mathrm{OMe}$ ), significant oligomerization did occur and in no case was a situation observed where a peptide ester was not turned over further on account of its low solubility.

The data obtained from these oligomerization experiments thus indicate that CPD-Y may be used to form mixtures of medium sized oligomers of the hydrophobic amino acids. This process was found to be specific for the L-isomer of the esters, a fact that should make it possible to use racemic starting material. Based on published results with endoprotease catalyzed condensation of peptide fragments $(9,11,12,13$, 18 ), it may become possible to isolate individual oligomeric fragments and couple them to produce monodisperse, optically pure poly- $\alpha$-amino acids of predetermined size.

As mentioned earlier, a further aspect of this work deals with the question of whether it might be possible to control the extent of oligomerization of amino acid esters and thus to utilize them for stepwise synthesis. In this context we have examined as amine components a series of amino acid alkyl esters where the size of the ester group was increased from methyl to ethyl, propyl, isopropyl and tert.-butyl. It was expected that these ester groups - acting as the leaving groups in the second elongation step - would interfere with optimal binding of the amine component to the enzyme and thus shift the partitioning of the acyl-enzyme in favor of hydrolysis. The net result would be the incorporation of one amino acid residue only, and the synthetic procedure outlined in Scheme 1 would be simplified by elimination of the deamidation step.

The experiments indicated that such an increase in the size of the alkyl ester group indeed resulted in a lower degree of oligomerization. However, with the sole exception of glycine, the coupling yields even in the reaction with the methyl ester of the initial acyl component were drastically reduced. For example, while the reaction of $\mathrm{H}-\mathrm{Met}-\mathrm{OMe}$ with $\mathrm{Bz}-\mathrm{Ala}-\mathrm{OMe}$ resulted in only $10 \%$ Bz-Ala-OH (the rest being converted to peptides), the reaction with H-MetOEt resulted in $60 \% \mathrm{Bz}-\mathrm{Ala}-\mathrm{OH}$, and the reaction with $\mathrm{H}-\mathrm{Met}-\mathrm{O}$ Pr resulted in $90 \% \mathrm{Bz}$ Ala-OH. Clearly, a small increase in the size of the alkyl ester group of the amine component results in sufficient sterical hindrance to interfere with the optimal binding required for maximal aminolysis to occur. Nevertheless, in view of the fact that the synthesis procedure can be shortened by the deamidation step, it may be advantageous in some cases to use the ethyl esters of amino acids as amine components. Especially for glycine, the alkyl esters may become the derivatives of choice for the incorporation of this amino acid in stepwise synthesis. With this amino acid, which probably binds sloppy due to lack of a side chain, all ester sizes tested (-OMe, -OEt, - $\mathrm{O}^{\mathrm{n} P r}$, -O Pr, - $\mathrm{O}^{\mathrm{i}} \mathrm{Bu}$ ) were incorporated well. In fact, the ester groups larger than methyl seem to contribute to a mode of binding that results in higher yields $(50 \%$ for methyl, $70-90 \%$ for the others). Furthermore, since the primary product of these reactions, a peptidyl-glycine ester, is turned over considerably slower than peptide esters with another amino acid in the ultimate position, it may often be possible to stop the reaction at a point where the peptidyl-glycine ester constitutes the major product. The synthesis can then directly be continued using as amine component the amide of the next amino acid to be incorporated.

In summary, the results presented in this paper indicate that alkyl esters of amino acids may in certain cases become useful alternatives to amino acid amides and amino acids as amine components in CPD-Y catalyzed peptide synthesis. Some of these esters can be employed as building blocks in stepwise synthesis and others may be used as substrates for the synthesis of poly- $\alpha$-amino acids of moderate length.

\section{ACKNOWLEDGEMENTS}

We thank professor MARTIN OTTESEN for discussions and for a critical reading of the manuscript. The technical assistance of Mss. Bodil Corneliussen and Edith Floistrup was excellent and is deeply appreciated. F. WIDMER gratefully acknowledges the Swiss National Science Foundation for a Fellowship. 


\section{REFERENCES}

1. Abderhalden, E. \& S. Suzuki: Studien über den Einfluss der an der Bildung von Aminosäureestern beteiligten Alkoholgruppe auf die Geschwindigkeit der Bildung von 2,5-Dioxopiperazinen und die Entstehung von Guanidinoverbindungen bei der Einwirkun von Guanidin auf verschiedene Aminosäureester. Z. Physiol. Chem. 176, 101-108 (1928)

2. Anderson, G. \& P. L. Luisi: Papain-induced oligomerization of $\alpha$-amino acid esters. Helv. Chim. Acta 62, 488-494 (1979)

3. Breddam, K., F, Widmer \& J. T. Johansen: Carboxypeptidase $Y$ catalyzed transpeptidations and enzymatic peptide synthesis. Carlsberg Res. Commun. 45, 237-247 (1980)

4. Breddam, K., F. Widmer \& J. T. Johansen: Influence of substrate structure on carboxypeptidase $\mathrm{Y}$ catalyzed peptide bond formation. Carlsberg Res. Commun. 45, 361-367 (1980)

5. Brenner, M. \& V. Kocher: Eine einfache enzymatische Methode zur Herstellung von Dund L-Methionin. Helv. Chim. Acta 32, 333337 (1949)

6. Brenner, M., E. Sailer \& K. Rüfenacht: Enzymatische Peptidsynthese. Peptidbildung aus DL-Threonin-isopropylester. Helv. Chim. Acta 34, 2096-2102 (1951)

7. Fruton, J. S.: Chemical aspects of protein synthesis. In: The Proteins. H. Neurath, ed., Academic Press, New York, Vol 1, 2nd ed., pp. 189-311 (1963)

8. GoldberG, M. I. \& J. S. Fruton: Beef liver esterase as a catalyst of acyl transfer to amino acid esters. Biochemistry 8, 86-97 (1969)

9. Isowa, Y., T. ICHIKaWa \& M. OHMORI: Peptide synthesis with proteinases. Fragment condensation of ZLeuGinGlyOH or ZGinGlyOH with HLeuValNH ${ }_{2}$ using metalloproteinases. Bull. Chem. Soc. Japan 51, 271-276 (1978)

10. Jost, R., E. Brambilla, J. C. Monti \& P. L. LuIsI: Papain catalyzed oligomerization of $\alpha$ - amino acids. Synthesis and characterization of water-insoluble oligomers of L-methionine. Helv. Chim. Acta 63, 375-384 (1980)

11. Morihara, K. \& T. OKa: $\alpha$-Chymotrypsin as the catalyst for peptide synthesis. Biochem. J. 163 , 531-542 (1977)

12. OKa, T. \& K. Morihara: Trypsin as a catalyst for peptide synthesis. J. Biochem. 82, 10551062 (1977)

13. Saltman, R., D. Vlach \& P. L. Luisi: Cooligopeptides of aromatic amino acids and glycine with variable distance between the aromatic residues. VII. Enzymatic synthesis of $\mathrm{N}$-protected amides. Biopolymers 16, 631-638 (1977)

14. Sluyterman, L. A. \& J. Wijdenes: Sigmoidal progress curves in the polymerization of leucine methyl ester catalyzed by papain. Biochim. Biophys. Acta 289, 195-202 (1972)

15. Widmer, F. \& J. T. Johansen: Enzymatic peptide synthesis. Carboxypeptidase $Y$ catalyzed formation of peptide bonds. Carlsberg Res. Commun. 44, 37-46 (1979)

16. Widmer; F., K. Breddam \& J. T. Johansen: Carboxypeptidase $Y$ as a catalyst for peptide synthesis in aqueous phase with minimal protection. In: Proc. 16th European Peptide Symposium, Brunfeldt, K., ed., scriptor, Copenhagen, pp. 46-55 (1981)

17. Widmer, F., K. Breddam \& J. T. Johansen: Influence of the structure of the amine component on carboxypeptidase $Y$ catalyzed peptide bond formation. Carlsberg Res. Commun. 46 (in press)

18. Wieland, Th.: Solution VS. Solid-phase methods in peptide chemistry. In: Versatility of proteins, Li C. H., ed., Academic Press, New York, pp. 59-80 (1978)

19. Wünsch, E.: Synthese von Peptiden. In: Houben-Weyl, Methoden der Organischen Chemie. E. Müller, ed., Thieme Verlag, Stuttgart, Vol. 15/1, pp. 1-27 (1974) 